\title{
Measurement Invariance pada Indonesian Tawadhu Scale (ITS)
}

\author{
Yonathan Natanael ${ }^{1}$, Mirna Devi ${ }^{2}$, Yasril Ananta Burhanudin ${ }^{3}$, Jamiludin Nur ${ }^{4}$ \\ 1,2,3,4 Fakultas Psikologi, Universitas Islam Negeri Sunan Gunung Djati Bandung, Indonesia \\ *e-mail: yonathan@uinsgd.ac.id
}

\begin{tabular}{|c|c|}
\hline Abstract / Abstrak & Keywords / Kata kunci \\
\hline $\begin{array}{l}\text { The purpose of this study to develop a new instrument of tawadhu that valid, } \\
\text { unbiased, and can be used in Indonesia. The research method uses combination } \\
\text { similarization in Islamic Psychological studies and psychological construction } \\
\text { scale. The number of participants in this research is } 613 \text { Muslims with range } 16 \\
\text { to } 45 \text { years old. Instrument consists of } 7 \text { items measuring intrapersonal dimension } \\
\text { and } 13 \text { items measuring interpersonal dimension. Methods that used measuring } \\
\text { instrument testing are Aiken validity and Multiple Groups Confirmatory Factor } \\
\text { Analysis (MGCFA) with a multidimensional model. The results of Aiken analysis } \\
\text { show that all items are valid measuring tawadhu. Also, MGCFA shows that } \\
\text { Indonesian Tawadhu Scale is an unbias scale. This instrument can be used by } \\
\text { Muslims in Indonesia as it integrates the concept of Psychology and Islam. }\end{array}$ & $\begin{array}{l}\text { Tawadhu; } \\
\text { Aiken Validity; } \\
\text { Measurement } \\
\text { Invariance }\end{array}$ \\
\hline $\begin{array}{l}\text { Penelitian ini bertujuan untuk mengembangkan alat ukur tawadhu yang valid, } \\
\text { tidak bias, dan dapat digunakan di Indonesia. Metode penelitian menggunakan } \\
\text { perpaduan pola similarisasi pada kajian Psikologi Islam dengan pengkonstruksian } \\
\text { alat ukur psikologi. Responden pada penelitian ini berjumlah } 613 \text { Muslim dengan } \\
\text { rentang usia } 16 \text { sampai dengan } 45 \text { tahun. Alat ukur tawadhu terdiri dari } 7 \text { item } \\
\text { mengukur dimensi intrapersonal dan } 13 \text { item mengukur dimensi interpersonal. } \\
\text { Metode pengujian alat ukur yang dilakukan adalah validitas Aiken dan Multiple } \\
\text { Group Confirmatory Factor Analysis (MGCFA) dengan model multidimensional. } \\
\text { Hasil analisis Aiken menunjukkan seluruh item valid mengukur tawadhu. } \\
\text { Demikian pula analisis MGCFA menunjukkan bahwa Indonesian Tawadhu Scale } \\
\text { tidak bias. Alat ukur ini dapat digunakan oleh Muslim di Indonesia karena adanya } \\
\text { perpaduan antara konsep Psikologi dan Islam. }\end{array}$ & $\begin{array}{l}\text { Tawadhu; } \\
\text { Validitas Aiken; } \\
\text { Measurement } \\
\text { Invariance }\end{array}$ \\
\hline
\end{tabular}

\section{Pendahuluan}

Rendah hati dalam ilmu Psikologi didefinisikan sebagai perilaku berinteraksi dengan orang lain secara positif yang melibatkan unsur penghargaan terhadap diri sendiri dan orang lain, baik itu kekurangan atau kelebihan seseorang (Davis dkk., 2011). Topik kerendahan hati menjadi sangat populer sebagai topik yang banyak diteliti beberapa tahun terakhir ini, khususnya pada aliran Psikologi Positif. Alasan kerendahan hati menjadi topik yang populer dalam penelitian karena banyaknya perbedaan definisi yang dikemukakan oleh tokoh-tokoh terkenal dan merupakan suatu hal yang positif yang ada pada manusia (Davis dkk., 2010).

Baru-baru ini rendah hati diartikan kembali oleh D'Errico (2020), menurutnya rendah hati sebagai suatu bentuk hubungan horizontal antara satu orang dengan orang lain yang di dalamnya terdapat sikap mengakui kekurangan pada diri seseorang, baik berupa pengetahuan maupun kompetensi. Bahkan, pada tahun 2020 ini rendah hati difokuskan dalam topik penelitian mengenai rendah hati seorang pemimpin (leader humility) pada suatu organisasi. Pada salah satu penelitan terbaru diketahui bahwa kerendahan hati seorang pemimpin menghasilkan hubungan dengan hasil kerja dan kepuasan karyawan (Qin dkk., 2020).

Bukti sikap kerendahan hati dapat dicontohkan oleh dua pimpinan organisasi ternama di negara Brazil dan Jepang (Vera \& Rodriguez-Lopez, 2004) yaitu pimpinan perusahaan Odebrecht Organization di Brazil 
yang memiliki 36.000 karyawan di empat benua dan Matsushita Electric Industrial Co.Ltd di Jepang. Kerendahan hati kedua pemilik perusahaan tersebut terkemuka saat adanya pertemuan Internasional, dimana perusahaan yang dikelola oleh kedua pemilik perusahaan tersebut memiliki kinerja yang sangat baik dan diakui di kancah Internasional. Namun, kedua pimpinan perusahaan tersebut bertekad untuk tidak masuk ke dalam kategori perusahaan sukses. Sebab bagi mereka berdua, kata "sukses" merupakan suatu perangkap yang dapat membuat seseorang melupakan hasil kualitas perusahaannya (Vera \& RodriguezLopez, 2004). Bagi kedua pimpinan perusahaan besar tersebut, memberikan yang terbaik bagi orang lain adalah hal yang paling utama untuk organisasinya. Hal ini menunjukkan gambaran kerendahan hati pimpinan organisasi yang termanifestasikan pada kinerja karyawan suatu organisasi.

Dalam ajaran Agama Islam, rendah hati dikenal dengan istilah tawadhu. Islam menganjurkan setiap muslim untuk tawadhu dalam hubungannya kepada Sang Pencipta dan sesamanya. Tawadhu dapat dipelajari dari sikap Nabi Muhammad Saw. dalam kehidupannya, bahkan dijelaskan dalam surah Alfurqan ayat 63: "Dan hamba-hamba Allah yang Maha Pengasih itu adalah orang-orang yang berjalan di bumi dengan rendah hati dan apabila orang bodoh (kafir) menyapa mereka (dengan katakata yang menghina), mereka mengucapkan "salam". Artinya hamba Allah yang beriman memiliki sifat tawadhu dalam kehidupan sosialnya, ditandai dengan mendapatkan kehormatan dan kemuliaan (Ummah, 2017).

Tawadhu berasal dari kata wadh'a yang memiliki arti merendah terhadap sesuatu dan ittadha'a yang artinya merendahkan diri (Rozak, 2017). Tawadhu merupakan perilaku menghargai dan memuliakan keberadaan orang lain (Libriastuti \& Sudewo, 2016). Sarihat (2019) mendefinisikan tawadhu sebagai sikap taat kepada Tuhan dan memperlakukan setiap manusia sama, tanpa melihat kelebihan dan kekurangannya. Orang yang tawadhu menurut Akhyar dan Wilaela (2018) termasuk orang yang disayang oleh Allah Swt. karena menjadi diri apa adanya (tidak membanggakan diri). Dijelaskan oleh Rozak (2017), tawadhu merupakan lawan kata dari takabur (dalam bahasa Indonesia berarti sombong), orang yang memiliki sifat tawadhu tidak pernah memandang dirinya lebih baik dari sesamanya, sedangkan sifat takabur memandang dirinya lebih dari sesamanya.

Tawadhu seorang muslim menurut Pardilah (2020) dilandasi oleh ridha Allah Swt., keimanan dan ketakwaan seseorang, dan amalan yang diperbuat dalam kehidupannya. Selain itu, menurut surah Alfurqan ayat 63, seseorang yang tawadhu atau sombong dapat dilihat dari cara berjalan, cara duduk, dan cara berdirinya. Sedangkan, Tiaranita dkk. (2017) menjelaskan beberapa ciri orang tawadhu, yakni: (a) mengenal dirinya sendiri, (b) mengenal Sang Pencipta, dan (c) diaplikasikan dalam aktivitas sosialnya. Ciri tawadhu tersebut senada dengan penelitian Bilicha dkk. (2019), yang mengatakan sikap yang ditunjukkan oleh seseorang yang tawadhu seperti merendahkan diri kepada sesama maupun kepada Allah Swt., mengakui kesalahan, keterbukaan, akhlak mulia, serta sifat terpuji yang ada dalam diri manusia.

Hidayanti (2016) menjelaskan dalam Tafsir Ibnu Katsir terdapat 21 karakteristik seseorang yang tawadhu, yakni: (1) lemah lembut kepada anak yatim, anak perempuan, orang lemah, dan orang miskin; (2) bersikap lembut terhadap mukmin; (3) kasih sayang terhadap mukmin dan para pemimpin; (4) bersikap keras terhadap orang kafir; (5) tidak mencela/ menghina orang lain; (6) taat kepada Allah dan Rasul; (7) tidak ghibah; (8) ketakwaan; (9) tidak menganggap diri suci; (10) tidak mengungkit amalan; (11) tidak merasa besar dengan kemuliaan, kedudukan, kekayaan; (12) mengucap salam kepada anak-anak; (13) bersikap lemah lembut; (14) keterbukaan; (15) berdiri bersama dengan orang yang membutuhkan; (16) tidak menghardik pemintaminta; (17) melakukan kebajikan; (18) menolong seseorang yang belum dikenal; (19) menjaga makanan yang jatuh; (20) tidak 
menolak hadiah; dan (21) meninggalkan kemewahan.

Munawaroh (2018) dalam penelitiannya menemukan empat aspek tawadhu yakni: berlaku lemah lembut, tidak merasa lebih baik dari orang lain, kesetaraan, dan mendahulukan kepentingan orang lain. Empat aspek ini merupakan hasil analisis faktor dari 26 item yang disusun dari sebelas indikator perilaku yang mengukur tawadhu, yakni: tidak membanggakan diri, menerima ilmu dari siapapun, menghargai orang lain, ringan tangan, bergaul dengan siapapun, mementingkan kepentingan orang lain, tidak mengandalkan orang lain, mengharapkan tempat terbaik dari Allah Swt., tidak membeda-bedakan sesama manusia, tidak merendahkan orang lain, dan bertutur kata yang baik.

Berbeda dengan konsep rendah hati dalam kajian ilmu Psikologi. Rendah hati merupakan gabungan dari dua komponen, yakni intrapersonal (humble, self-enhancement) dan interpersonal (respect to other, empathy, lack of superiority, social acceptance, openess) (Davis dkk., 2010). Perbedaan rendah hati dan tawadhu hanya terlihat pada banyaknya aspek yang dihasilkan, namun seluruh aspek dari kedua konsep tersebut mengukur hal yang sama, misalnya lemah lembut dengan humble, tidak merasa lebih baik dengan selfenhancment, kesetaraan dengan lack superiority, mendahulukan kepentingan orang lain dengan respect for others.

Berkaitan dengan social acceptance dan empathy apabila dilihat pada sebelas indikator tawadhu menurut Munawaroh (2018) pada paragraf sebelumnya, memiliki makna yang sama dengan bergaul dengan siapapun dan menghargai orang lain. Selain itu, apabila merujuk kepada Hidayanti (2016), social acceptance dan empathy merupakan karakteristik orang yang tawadhu, karena salah satu karakteristik orang tawadhu adalah berdiri bersama dengan orang yang membutuhkan, hal ini menunjukkan adanya rasa empati dan social acceptance. Hal ini menegaskan kembali pernyataan dari Munawaroh (2018) bahwa rendah hati dan tawadhu memiliki kesamaan dalam konsep. Selain konsep, dari definisi, ciri, dan sikap tawadhu dalam penjabaran paragraf di atas, tawadhu selaras dengan rendah hati (humility) Davis dkk. (2017) dalam kajian ilmu Psikologi. Kedua variabel tersebut terlihat berbeda, namun artinya sama. Jadi, secara konseptual, rendah hati dan tawadhu dapat dilinierkan penggunaan istilahnya.

Ditinjau dari hasil-hasil penelitian sebelumnya, pengukuran konsep rendah hati dalam ilmu Psikologi telah banyak dilakukan oleh pakar-pakar di bidang Psikologi. Alat ukur rendah hati yang sudah dikenalkan oleh beberapa ahli, yakni: Comprehensive Intellectual Humility Scale (Krumrei-Mancuso \& Rouse, 2016), Experience Humility Scale (Davis dkk., 2017), Brief State Humility Scale (Kruse dkk., 2017), Multidimensional Cultural Humility Scale (Gonzalez dkk., 2020), Relation Humility Scale (Davis dkk., 2011), Rosemade Humility Scale (Davis \& Hook, 2014).

Permasalahan yang terjadi di Indonesia, khususnya mengenai alat ukur tawadhu yang dikembangkan apabila dicari pada google cendekia, hanya terdapat satu alat ukur yang diterbitkan. Munawaroh (2018) dalam penelitiannya membuat alat ukur tawadhu secara langsung dari kumpulan beberapa ayat Alquran dan Hadis. Kumpulan ayat dan Hadis yang digunakan menghasilkan sebelas indikator perilaku tawadhu. Pada umumnya suatu alat ukur dihasilkan melalui penurunan dari teori ke dalam aspek, kemudian dari aspek menjadi indikator. Dari indikator tersebut diturunkan menjadi item-item. Namun alat ukur tawadhu yang dikembangkan Munawaroh (2018) tidak berpatokan kepada teori maupun aspek, melainkan langsung kepada indikator tawadhu.

Salah satu kekurangan alat ukur tawadhu yang dikembangkan oleh Munawaroh adalah belum adanya teori dasar yang membagi itemitem alat ukur ke dalam aspek-aspek dalam suatu variabel, sehingga dalam penganalisisan validitasnya menggunakan Keiser Meyer Olkin - Barlett Test (KMO-Barlett), yang mana peneliti masih mencari aspek-aspek dari tawadhu. Disamping itu, pada aspek 'mendahulukan kepentingan orang lain' 
dihasilkan nilai reliabilitas sebesar .685 , kurang dari batasan nilai reliabilitas yang baik yakni > .70 (Tanidir dkk., 2017).

Kekurangan lainnya pada alat ukur tawadhu yang dikembangkan oleh Munawaroh (2018) adalah jumlah partisipan yang digunakan dalam penelitiannya, yakni sebanyak 131 partisipan. Dari 26 item yang dikembangkan hanya disebarkan kepada 131 partisipan penelitian. Hal ini bertentangan dengan aturan pengujian suatu alat ukur, dimana satu item yang dibuat dalam suatu alat ukur harus diujikan oleh sepuluh partisipan atau jumlah item (n) dikali sepuluh (Cohen dkk., 2013). Artinya, alat ukur tawadhu yang dikembangkan oleh Munawaroh belum memenuhi batasan partisipan penelitian dalam mengkonstruk suatu alat ukur maupun batasan uji coba alat ukur baru.

Terdapat pula kelebihan alat ukur yang dikembangkan oleh Munawaroh (2018). Apabila diujikan seluruh item secara bersamaan, nilai reliabilitas all item yang dihasilkan sebesar $.896>.70$, nilai tersebut menunjukkan bahwa alat ukur yang dibuat konsisten bisa diujikan bersama. Kelebihan lainnya adalah partisipan penelitian yang homogen yaitu santri-santri pada salah satu pondok pesantren. Dengan demikian dapat dilihat perbedaan dalam membuat alat ukur rendah hati dari sisi Psikologi dan Islam. Ahliahli Psikologi dari berbagai negara membuat alat ukur rendah hati berdasarkan dari teori Psikologi, di Indonesia seorang peneliti membuat alat ukur berdasarkan ayat-ayat Alquran dan Hadis. Dua cara yang sangat berbeda dalam konstruksi alat ukur rendah hati.

Pada zaman modern ini, sifat tawadhu semakin meluntur di masyarakat, yang disebabkan oleh kurangnya pengajaran mengenai moral. Apabila dikaitkan dengan teori perkembangan, pelajaran mengenai moral sangat baik diajarkan sejak usia Taman KanakKanak (Tarsono dkk., 2020). Dari sisi Pendidikan Agama Islam, tawadhu merupakan salah satu bentuk akhlak karimah (Gade, 2019). Sikap tawadhu sangat penting diajarkan dari fase individu memasuki usia Sekolah Dasar
(SD) sampai Sekolah Menengah Atas (SMA) (Rohman, 2020). Ditegaskan pula oleh pendapat Ibn Khaldun yang mengungkapkan bahwa pendidikan akhlak dibangun sejak seseorang menjadi peserta didik (Darma, 2020).

Melalui pendidikan, individu tidak hanya diajarkan tentang pengetahuan, tetapi juga diajarkan menjadi pribadi yang berakhlak. Rasulullah Saw. Bersabda: "Orang mukmin yang paling sempurna imannya ialah orang yang paling bagus akhlaknya" (HR. Bukhari) dan "Sesungguhnya orang yang paling aku cintai dan yang paling dekat denganku tempatnya pada hari kiamat adalah yang terbaik akhlaknya di antara kalian" (HR. Tirmidzi). Kedua Hadis tersebut apabila dikaitkan dengan teori perkembangan dapat disimpulkan bahwa untuk mempelajari akhlak (salah satunya adalah tawadhu) tidak dibatasi oleh usia, karena tawadhu merupakan pelajaran untuk seluruh manusia dari seluruh kalangan dengan waktu sepanjang hayat. Oleh sebab itu, dalam kehidupan saat ini tawadhu merupakan suatu hal yang penting dimiliki oleh individu, karena dengan bersikap tawadhu berarti individu mengamalkan pelajaran akidah akhlak serta dapat meredam suatu gesekan pada satu individu kepada individu lainnya karena adanya perasaan tidak dihargai (Rohman, 2020).

Berdasarkan penelitian-penelitian sebelumnya, tawadhu memiliki kaitan dengan kesejahteraan psikologis (Munawaroh, 2018). Dari hasil penelitian ditemukan bahwa tawadhu memiliki korelasi positif dengan kesejahteraan psikologis (nilai $\mathrm{r}=.492$ ), artinya semakin seseorang bersikap tawadhu, maka kesejahteraan psikologisnya semakin baik. Tawadhu pun memberikan pengaruh yang cukup besar kepada kesejahteraan psikologis seseorang, yang mana dihasilkan nilai $R$ Square sebesar $24 \%$. Penelitian lainnya menyebutkan bahwa, tawadhu dapat dipengaruhi oleh dua variabel yakni religiusitas dan kecerdasan emosi (Tiaranita dkk., 2017). Dapat disimpulkan dari persamaan regresi yang dihasilkan "tawadhu $=\mathrm{a}+.232$ religiusitas + .278 kecerdasan emosi”. Tawadhu dalam 
penelitian dapat menjadi variabel independen maupun variabel dependen.

Oleh karena pentingnya pengukuran tawadhu pada individu, serta adanya perbedaan cara mengkonstruk tawadhu dari segi Psikologi dan Islam. Peneliti melihat ada kesempatan yang sangat baik untuk membangun konstruk alat ukur tawadhu berdasarkan gabungan teori humility Davis dkk. (2017) dari ilmu Psikologi, ayat-ayat Alquran dan Hadis untuk digunakan di Indonesia. Pengembangan alat ukur tawadhu dalam penelitian ini bertujuan untuk memperoleh alat ukur yang valid, tidak bias dan dapat digunakan di Indonesia.

\section{Metode}

\section{Desain Penelitian}

Penelitian yang dilakukan, dirancang menggunakan metode tematik (madhu'i), pendekatan skripturalis, pola similarisasi dari Mujib (2005) dan pengkonstruksian alat ukur psikologi dari DeCoster (2005). Perpaduan dua metode ini akan dibahas pada prosedur penelitian

\section{Partisipan Penelitian}

Partisipan penelitian ini adalah 613 muslim di Indonesia. Teknik sampling yang digunakan adalah purposive sampling, dimana kriteria pada partisipan, yakni memiliki rentang usia 16 - 45 tahun dan beragama Islam. Rentang usia tersebut merupakan tingkat remaja sampai dengan dewasa madya, hal ini senada dengan teori perkembangan dimana remaja adalah individu yang berusia 11 - 20 tahun (Vijayakumar dkk., 2016), sedangkan dewasa madya awal adalah individu berusia 40 - 55 tahun (Chompalov dkk., 2018).

Peneliti meminta kesediaan partisipan penelitian untuk mengisi kuesioner online dalam bentuk google form dari link https://forms.gle/YiTiASybkXivjDdu5, link tersebut disebarkan menggunakan media sosial yakni Whatsapp dan Instagram. Yang diutamakan menjadi partisipan penelitian adalah orang-orang terdekat peneliti, seperti teman, sahabat, keluarga. Selain orang terdekat, peneliti menyebarkan link kepada seluruh kontak yang berada dalam media sosial peneliti. Penelitian ini dilakukan pada masa pandemi Covid-19 yang sedang melanda seluruh dunia. Jadi, peneliti beranggapan bahwa cara terbaik untuk mengambil data adalah menggunakan media sosial, demi menjaga kesehatan bersama.

\section{Alat Ukur Penelitian}

Alat ukur yang dikonstruksi oleh peneliti diberi nama Indonesian Tawadhu Scale (ITS). Dimana alat ukur yang dikonstruk terdiri dari 20 item yang mengukur tawadhu dengan 5 alternatif jawaban (skala likert). Seluruh item dianalisis menggunakan validitas Aiken dan multiple group analisis faktor konfirmatori. Validitas Aiken digunakan untuk memastikan kesesuaian item dengan konstruk yang diukur berdasarkan pandangan 5 orang ahli, sedangkan multiple group analisis faktor konfirmatori digunakan untuk mengetahui terjadi bias atau tidak pada alat ukur yang dibuat.

\section{Prosedur Penelitian}

Prosedur pembuatan ITS menggunakan beberapa langkah. Peneliti mencoba menggabungkan pola pendekatan Psikologi Islam dan langkah-langkah konstruksi skala. Pengembangan Psikologi Islam menurut Mujib (2005) dapat dilakukan melalui metode, pendekatan dan pola dalam studi Islam. Metode yang digunakan antara lain: metode madhu'i, metode tahlili, metode muqarin, dan metode ijmali. Pendekatan yang digunakan skripturalis, falsafi, dan tasawwufi. Pola yang digunakan similarisasi, paralelisasi, komplementasi, dan komparasi. Adapun tahapan untuk melakukan konstruksi skala menurut DeCoster (2005) adalah creating item, data collection, validity dan reliability, revision, dan reporting scale. 


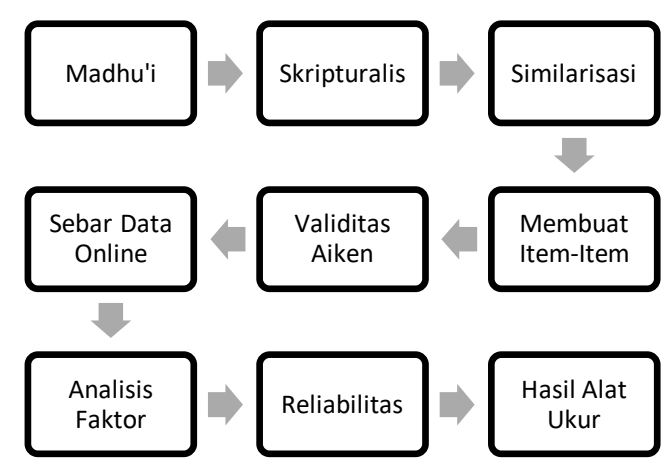

Gambar 1. Langkah pembuatan alat ukur ITS

$\begin{array}{rrr}\text { Dari pendekatan } & \text { Psikologi } & \text { Islam dan } \\ \text { konstruksi } & \text { skala } & \text { tersebut, peneliti }\end{array}$ menggabungkannya menjadi 9 langkah. Langkah-langkah tersebut peneliti lakukan sebagai bentuk gabungan dari dua kajian yang berbeda, dimana langkah-langkah awal pembuatan alat ukur ITS ini melalui pendekatan Psikologi Islam yang dipadukan dengan teori Konstruksi Tes. Adapun langkah-langkahnya sebagai berikut: (1) mengikuti metode tematik (madhu'i), (2) pendekatan skripturalis, (3) pola similarisasi, (4) membuat item, (5) validasi item oleh pakar (validitas Aiken), (6) mengambil data penelitian (7) analisis faktor konfirmatori, (8) reliabilitas alat ukur yang dibuat, (9) hasil alat ukur jadi.

Tabel 1

Blue Print Indonesian Tawadhu Scale

\begin{tabular}{|c|c|c|}
\hline Dimensi & Indikator & Item \\
\hline Intrapersonal & $\begin{array}{l}\text { Self- } \\
\text { enhancement }\end{array}$ & $\begin{array}{l}\text { 1. Saya menghargai pendapat orang lain } \\
\text { 2. Saya mudah bergaul dengan siapa saja } \\
\text { 3. Saya berteman dengan siapa pun } \\
\text { 4. Saya mengembangkan skill dengan belajar lebih keras } \\
\text { 5. Saya senang berada di dalam lingkungan yang positif } \\
\text { 6. Saya termotivasi untuk mendapatkan hasil yang terbaik } \\
\text { 7. Saya menghargai setiap proses dari pekerjaan yang saya lakukan }\end{array}$ \\
\hline Interpersonal & $\begin{array}{l}\text { Respect for } \\
\text { others }\end{array}$ & $\begin{array}{l}\text { 8. Saya mendengarkan dengan serius ketika orang lain berbicara } \\
\text { 9. Saya memberi salam ketika bertemu orang lain } \\
\text { 10. Saya kurang peduli dengan pendapat orang lain (-) }\end{array}$ \\
\hline & Empathy & $\begin{array}{l}\text { 11. Saya merasa sedih ketika melihat teman saya terkena musibah } \\
\text { 12. Saya bahagia melihat teman saya bahagia }\end{array}$ \\
\hline & Lack of & 13. Saya dapat berdiskusi dengan siapapun \\
\hline & $\begin{array}{l}\text { Social } \\
\text { acceptance } \\
\text { Openess }\end{array}$ & $\begin{array}{l}\text { 15. Saya berperilaku wajar saat bersama orang lain } \\
\text { 16. Saya menghormati budaya dimana saya tinggal } \\
\text { 17. Saya senang berteman dengan orang yang baru saya kenal } \\
\text { 18. Saya senang menerima masukan dan saran dari orang lain } \\
\text { 19. Saya mendukung siapapun yang terpilih menjadi pemimpin } \\
\text { 20. Saya berdiskusi dengan semua teman apapun perbedaannya }\end{array}$ \\
\hline
\end{tabular}

Pertama, metode tematik (madhu'i) yang dilakukan oleh peneliti adalah mencari konsep Psikologi yang selaras dengan konsep Islami. Peneliti menemukan kesamaan konsep pada variabel humility (Davis dkk., 2011) dan tawadhu dalam beberapa ayat Alquran dan beberapa sumber Hadis, yang masing-masing memiliki arti rendah hati. Kedua, pendekatan skripturalis yaitu peneliti mengumpulkan ayatayat dalam Alquran dan beberapa Hadis yang berkaitan dengan konsep tawadhu. Dalam pengumpulan ayat didapatkan bahwa ada kesamaan antara konsep operasional humility dan tawadhu.

Ketiga, yaitu teknik similarisasi konsep humility dan tawadhu dilakukan saat pembuatan blueprint alat ukur ITS. Seluruh indikator humility sesuai dengan tafsir Ibnu Katsir (AdDimasyqi, 2000) dalam Alquran dan Hadis. Terjadi kesamaan dalam keterangan setiap indikator dan tafsir ayat-ayat Alquran dan Hadis.

Langkah kesatu sampai ketiga mengikuti pola pengembangan Psikologi Islam (Mujib, 2005). Langkah keempat yang dilakukan adalah menurunkan indikator menjadi item dapat dilihat pada blue print di tabel 1. Adapun langkah kelima sampai langkah terakhir 
merupakan tujuan utama penelitian ini yang akan dibahas pada hasil penelitian.

Indikator humble pada alat ukur ITS sesuai dengan penjelasan surah Luqman: 18-19 yang berbunyi: "Dan janganlah kamu memalingkan wajah dari manusia (karena sombong) dan janganlah kamu berjalan di muka bumi dengan penuh keangkuhan. Sesungguhnya Allah tidak menyukai orang-orang yang sombong lagi membanggakan diri. Dan sederhanalah kamu dalam berjalan dan lunakkanlah suaramu. Sesungguhnya seburuk-buruk suara ialah suara keledai". Ayat tersebut memiliki makna seseorang yang tawadhu memiliki sikap sopan santun dan menghormati orang lain dalam tutur kata dan perbuatan.

Indikator self-enhancement dijelaskan dalam surah Alisra ayat 37 yang berbunyi: "Dan janganlah engkau berjalan di muka bumi ini dengan sombong, karena sesungguhnya engkau tidak akan dapat menembus bumi dan tidak akan mampu menjulang setinggi gunung”. Selanjutnya Hadis dari Abu Bakar Ash-Shidiq: "Kami dapati kemuliaan itu datang dari sifat takwa, qana'ah (merasa cukup), muncul karena yakin (pada apa yang ada di sisi Allah), dan kedudukan yang mulia didapat dari sifat tawadhu". Ayat dan Hadis menjelaskan pada individu agar tidak menyombongkan diri dan untuk seorang yang tawadhu, Allah akan meningkatkan derajatnya.

Indikator respect for others, seperti yang tertulis dalam Hadis riwayat Muslim XVII/200 dalam Syarh Shahiih Muslim, Imam anNawawi: "Sesungguhnya Allah mewahyukan kepadaku agar kalian bertawadhu, sehingga seseorang tidak merasa bangga lagi sombong terhadap orang lain dan tidak pula berlaku aniaya kepada orang lain". Dapat dijelaskan bahwa salah satu bentuk sikap yang ada pada orang yang tawadhu adalah yakni memiliki kepedulian serta menolong terhadap sesamanya.

Indikator empathy sesuai perilaku yang dicontohkan Rasulullah Saw. yang tertulis pada kitab Al Barzanji karya Syaikh Ja'far bin Husin bin Abdul Karim bin Muhammad yang menyatakan bahwa: "Rasulullah Saw. adalah pribadi yang sangat pemalu dan amat tawadhu'.... beliau mencintai fakir miskin dan tidak segan-segan bergaul dengan duduk bersama mereka dan menjenguk mereka yang sakit". Hadis tersebut menjelaskan bahwa salah satu sifat Rasul adalah tawadhu, dimana terdapat rasa empati yang ditunjukkan kepada golongan orang yang kurang mampu.

Indikator lack of superiority tertulis dalam dua surah, yakni surah Alhijr ayat 88 yang berarti: "Janganlah sekali-kali kamu menunjukkan pandanganmu kepada kenikmatan hidup yang telah Kami berikan kepada beberapa golongan di antara mereka (orangorang kafir itu), dan janganlah kamu bersedih hati terhadap mereka dan berendah dirilah kamu terhadap orang-orang yang beriman", dan surah Annisa ayat 36 yang berarti: "Sesungguhnya Allah tidak menyukai orangorang yang sombong dan membanggabanggakan diri". Kedua ayat menjelaskan bahwa individu yang tawadhu pasti tidak membanggakan dirinya berlebih atau merasa dirinya lebih dari orang lain.

Indikator social acceptance dijelaskan pada surah Alfurqan ayat 63 yang berbunyi: "Dan hamba-hamba Tuhan Yang Maha Penyayang itu (ialah) orang-orang yang berjalan di atas bumi dengan rendah hati dan apabila orang-orang jahil menyapa mereka, mereka mengucapkan kata-kata (yang mengandung) keselamatan". Ayat tersebut menjelaskan bahwa sifat tawadhu mudah diterima masyarakat luas, karena seluruh manusia pasti menyukai orang yang tawadhu. Dimana orang tawadhu lebih mudah menambahkan teman atau sahabat.

Indikator openess tertulis dalam surah Asysyuaraa ayat 214-215 yang berbunyi: “... dan berilah peringatan kepada kerabatkerabatmu yang terdekat dan rendahkanlah dirimu terhadap orang-orang yang mengikutimu. Yaitu orang-orang yang beriman". Pada ayat tersebut dijelaskan bahwa salah satu sikap orang tawadhu adalah menerima suatu masukan dari orang lain. 


\section{Hasil}

Dari hasil penyebaran kuesioner online, didapatkan partisipan penelitian berjenis kelamin perempuan sebanyak 444 orang (72.4\%) dan laki-laki 169 orang (27.6\%) dengan rentang usia 16 sampai dengan 45 tahun. Pekerjaan partisipan penelitian sebesar 71.8\% pelajar/ mahasiswa, 9.8\% karyawan, dan $3.4 \%$ guru (sisanya ada sebagai Ibu Rumah Tangga, PNS, Pengacara, Polisi, Desainer, Apoteker, dan jenis pekerjaan lainnya). Mayoritas status pernikahan partisipan $93.6 \%$ belum menikah dan sisanya sudah menikah.

Pada bagian ini akan dibahas hasil analisis data ITS menggunakan analisis Aiken dan Measurement Invariance (MI). Pemilihan dua teknik analisis didasari oleh dua alasan. Alasan pertama dalam mengkonstruk alat ukur sangat diperlukan penilaian dari pakar yang ahli dalam bidangnya, guna menetapkan bahwa item yang dikonstruk sesuai atau tidak dengan variabel yang diukur. Setelah didapatkan analisis Aiken berdasarkan pakar, item-item tersebut kemudian disebarkan kepada partisipan guna pengujian konstruk alat ukur. Uji validitas konstruk tersebutlah yang menjadi alasan kedua peneliti melakukan analisis measurement invariance. Disamping itu, kelebihan measurement invariance tidak hanya menganalisis sampai dengan melihat item valid atau tidak, melainkan dapat mengetahui bias yang terjadi pada suatu item yang dikonstruk. Jadi, pemilihan dua teknik analisis pada intinya ingin mengetahui penilaian dari dua sisi, baik dari pakar maupun partisipan penelitian.

\section{Validitas Aiken}

Berdasarkan tabel validitas Aiken (1985), untuk mengetahui batasan item valid atau tidak dengan jumlah rater sebanyak lima orang dan jumlah pilihan jawaban sebanyak lima jawaban adalah sebesar .80 dengan taraf signifikan lima persen. Selanjutnya 20 item yang dibuat dihitung satu per satu menggunakan rumus $\mathrm{V}=$ $\mathrm{S} /[\mathrm{n}(\mathrm{c}-1)]$, hasil perhitungan Aiken dijabarkan pada tabel 2 .
Tabel 2 menunjukkan bahwa seluruh item valid berdasarkan perhitungan Aiken, karena mencapai batasan yang sesuai dan ada pula yang melebihi batasan .80. Langkah selanjutnya mengetahui apakah terjadi bias atau tidak pada 20 item yang dikonstruk. Bias yang dimaksud adalah bias berdasarkan gender antara kelompok laki-laki dan kelompok perempuan menggunakan teknik analisis multiple group.

\section{Measurement Invariance (MI)}

Dalam penganalisisan Measurement Invariance pada suatu alat ukur, diperlukan beberapa kali penganalisisan sampai mendapatkan hasil maksimal. Karena alat ukur ITS yang dibuat diharapkan tidak mengalami bias gender, maka peneliti melakukan analisis terlebih dahulu pada masing-masing kelompok, yaitu melakukan Confirmatory Factor Analysis (CFA) dengan model multidimensional pada tiap kelompok, yang kemudian diujikan pada CFA gabungan dari kelompok laki-laki dan perempuan. Langkah terakhir menganalisis dengan Multiple Group Confirmatory Factor Analysis (MGCFA).

Tabel 2

Hasil Perhitungan Validitas Aiken ITS

\begin{tabular}{lcl}
\hline No Item & Nilai Aiken & Hasil \\
\hline 1 & 1.00 & Valid \\
2 & .85 & Valid \\
3 & .90 & Valid \\
4 & .80 & Valid \\
5 & .80 & Valid \\
6 & .85 & Valid \\
7 & .80 & Valid \\
8 & .80 & Valid \\
9 & 1.00 & Valid \\
10 & .85 & Valid \\
11 & 1.00 & Valid \\
12 & 1.00 & Valid \\
13 & 1.00 & Valid \\
14 & .80 & Valid \\
15 & .80 & Valid \\
16 & 1.00 & Valid \\
17 & .95 & Valid \\
18 & .95 & Valid \\
19 & .90 & Valid \\
20 & .80 & Valid \\
\hline
\end{tabular}


Tabel 3

Rangkuman Penganalisisan

\begin{tabular}{lccccc}
\hline Model Fit & $\begin{array}{c}\text { Kelompok } \\
(\mathrm{P})\end{array}$ & $\begin{array}{c}\text { Kelompok } \\
(\mathrm{L})\end{array}$ & $\begin{array}{c}\text { Gabungan } \\
(\mathrm{P} \& \mathrm{~L})\end{array}$ & $\begin{array}{c}\text { Scalar } \\
\text { Invariance }\end{array}$ & $\begin{array}{c}\text { Residual } \\
\text { Invariance }\end{array}$ \\
\hline Chi-Square & 609.254 & 331.836 & 755.494 & 1062.251 & 1145.633 \\
Df & 166 & 168 & 166 & 377 & 397 \\
P-Value & .00 & .00 & .00 & .00 & .00 \\
RMSEA - & .078 & .076 & .076 & .077 & .078 \\
[CI 90\%] & {$[.071-.084]$} & {$[.064-.088]$} & {$[.071-.082]$} & {$[.072-.082]$} & {$[.073-.084]$} \\
CFI & .889 & .920 & .908 & .755 & .732 \\
TLI & .884 & .909 & .895 & .753 & .744 \\
\hline
\end{tabular}

Keterangan: $\mathrm{P}=$ Perempuan, $\mathrm{L}=$ Laki-laki

Kriteria model fit yang digunakan adalah RMSEA, yang mana dengan nilai RMSEA < .08 dalam penganalisisan model sudah mendapatkan model yang fit (Ho dkk., 2015). Selain itu, RMSEA adalah patokan dalam menentukan model fit yang konsisten, walaupun berbeda-beda sampel penelitian, tetap menunjukkan nilai yang konsisten. Dalam arti RMSEA merupakan kriteria model fit yang tidak terpengaruhi oleh banyaknya partisipan. Peneliti merangkum hasil pada masing-masing jenis penganalisisan sebagaimana disajikan pada tabel 3 .

Penganalisisan pada kelompok perempuan dengan nilai $\chi_{(166)}^{2}=609.254, p<.05 \&$ RMSEA < .08 didapatkan seluruh item memiliki nilai loading factor yang baik, dari item 1 sampai dengan item 20 dapat dilihat pada tabel 4. Dimensi intrapersonal dari item 1 sampai item 7 dan dimensi interpersonal dari item 8 sampai item 20. Hal ini sejalan dengan penelitian Salsabila dkk. (2019) dimana item yang baik memiliki nilai loading factor/ estimatel daya beda $>.30$.

Pada kelompok laki-laki dengan nilai $\chi^{2}{ }_{(168)}$ $=331.836, p<.05 \&$ RMSEA $<.08$ seluruh item memiliki nilai loading factor lebih besar dari .30 yang dapat dilihat pada tabel 5 . Analisis CFA dengan model multidimensional pada kelompok gabungan dengan nilai $\chi_{(166)}^{2}=$ 755.494, $p<.05 \&$ RMSEA $<.08$ diketahui pula, seluruh item valid dan mengukur dimensi yang diukur, yang dapat dilihat pada gambar 2 . Baik pada dimensi intrapersonal maupun interpersonal tidak ada satu pun item yang memiliki nilai loading factor di bawah .30 .
Untuk dimensi intrapersonal nilai loading factor terendah dari ketujuh item adalah .416 terdapat pada item 2, sedangkan untuk dimensi interpersonal nilai loading factor terendah adalah .377 pada item 10. Dari kelompok gabungan atau bisa disebut seluruh partisipan penelitian dihasilkan nilai Construct Reliability $(\mathrm{CR})=.98$ dan Variance Extracted $(\mathrm{VE})=.93$ untuk aspek intrapersonal, serta $\mathrm{CR}=.98$ dan $\mathrm{VE}=.91$ untuk aspek interpersonal. Artinya, kedua aspek yang mengukur tawadhu reliabel dan valid seluruh itemnya.

Tabel 4

CFA Kelompok Perempuan

\begin{tabular}{ccccc}
\hline $\begin{array}{c}\text { No } \\
\text { Item }\end{array}$ & $\begin{array}{c}\text { Factor } \\
\text { Loading }\end{array}$ & Error & Signifikansi & Hasil \\
\hline 1 & .564 & .045 & .000 & Valid \\
2 & .382 & .050 & .000 & Valid \\
3 & .531 & .042 & .000 & Valid \\
4 & .509 & .036 & .000 & Valid \\
5 & .515 & .053 & .000 & Valid \\
6 & .677 & .035 & .000 & Valid \\
7 & .689 & .035 & .000 & Valid \\
8 & .591 & .035 & .000 & Valid \\
9 & .496 & .040 & .000 & Valid \\
10 & .421 & .042 & .000 & Valid \\
11 & .568 & .037 & .000 & Valid \\
12 & .644 & .033 & .000 & Valid \\
13 & .640 & .029 & .000 & Valid \\
14 & .536 & .037 & .000 & Valid \\
15 & .457 & .041 & .000 & Valid \\
16 & .717 & .031 & .000 & Valid \\
17 & .547 & .034 & .000 & Valid \\
18 & .630 & .028 & .000 & Valid \\
19 & .413 & .044 & .000 & Valid \\
20 & .608 & .034 & .000 & Valid \\
\hline
\end{tabular}


Tabel 5

CFA Kelompok Laki-laki

\begin{tabular}{ccccc}
\hline $\begin{array}{c}\text { No } \\
\text { Item }\end{array}$ & $\begin{array}{c}\text { Factor } \\
\text { Loading }\end{array}$ & Error & Signifikansi & Hasil \\
\hline 1 & .610 & .061 & .000 & Valid \\
2 & .547 & .056 & .000 & Valid \\
3 & .596 & .055 & .000 & Valid \\
4 & .622 & .046 & .000 & Valid \\
5 & .628 & .054 & .000 & Valid \\
6 & .712 & .051 & .000 & Valid \\
7 & .722 & .059 & .000 & Valid \\
8 & .665 & .045 & .000 & Valid \\
9 & .572 & .050 & .000 & Valid \\
10 & .310 & .057 & .000 & Valid \\
11 & .508 & .063 & .000 & Valid \\
12 & .404 & .071 & .000 & Valid \\
13 & .605 & .049 & .000 & Valid \\
14 & .514 & .052 & .000 & Valid \\
15 & .481 & .064 & .000 & Valid \\
16 & .688 & .051 & .000 & Valid \\
17 & .581 & .052 & .000 & Valid \\
18 & .739 & .041 & .000 & Valid \\
19 & .575 & .055 & .000 & Valid \\
20 & .747 & .037 & .000 & Valid \\
\hline
\end{tabular}

Selanjutnya adalah penganalisisan Measurement Invariance (MI), konsep MI dikenalkan oleh Meredith (1993) yang hasil penganalisisannya hampir menyerupai hasil penganalisisan dengan metode Differential Item Functioning (DIF) dalam Item Response Theory (IRT). Alat ukur ITS yang dikembangkan peneliti dianalisis dengan MGCFA pada model multidimensional dengan menggunakan software MPlus guna mengetahui tingkat MI pada alat ukur ITS.

Perlu diketahui terlebih dahulu bahwa pengujian MI berdasarkan urutannya dari configural invariance (nilai loading factor, intercept, dan residual untuk tiap-tiap item berbeda antar kelompok), metrix invariance (nilai loading factor sama, intercept dan residual untuk tiap-tiap item berbeda antar kelompok), scalar invariance (nilai loading factor dan intercept sama, hanya nilai residual untuk tiap-tiap item berbeda antar kelompok) dan residual invariance (nilai loading factor, intercept dan residual untuk tiap-tiap item sama antar kelompok). Kecanggihan software MPlus dalam penganalisisan MI adalah default bawaan dari software MPlus adalah scalar invariance (dalam arti, pengujian MI dimulai pada model scalar invariance).
Tabel 6

Scalar Invariance ITS

\begin{tabular}{|c|c|c|c|c|}
\hline $\begin{array}{c}\text { No } \\
\text { Item }\end{array}$ & $\begin{array}{c}\text { Factor } \\
\text { Loading }\end{array}$ & Intercept & Residual & Hasil \\
\hline \multirow[t]{2}{*}{1} & .265 & 4.474 & .272 & Perlu \\
\hline & .265 & 4.474 & .243 & $\begin{array}{l}\text { diwaspadai } \\
\text { Perlu } \\
\text { diwaspadai }\end{array}$ \\
\hline \multirow[t]{2}{*}{2} & .352 & 3.773 & .775 & Tidak bias \\
\hline & .352 & 3.773 & .724 & Tidak bias \\
\hline \multirow[t]{2}{*}{3} & .397 & 4.091 & .513 & Tidak bias \\
\hline & .397 & 4.091 & .617 & Tidak bias \\
\hline \multirow[t]{2}{*}{4} & .386 & 4.015 & .440 & Tidak bias \\
\hline & .386 & 4.015 & .439 & Tidak bias \\
\hline \multirow[t]{3}{*}{5} & .258 & 4.629 & .258 & Perlu \\
\hline & 258 & 4620 & 290 & $\begin{array}{r}\text { diwa } \\
P\end{array}$ \\
\hline & & $7.02)$ & & diwaspadai \\
\hline \multirow[t]{2}{*}{6} & .357 & 4.482 & .228 & Tidak bias \\
\hline & .357 & 4.482 & .290 & Tidak bias \\
\hline \multirow[t]{2}{*}{7} & .345 & 4.484 & .233 & Tidak bias \\
\hline & .345 & 4.484 & .192 & Tidak bias \\
\hline \multirow[t]{2}{*}{8} & .356 & 4.168 & .313 & Tidak bias \\
\hline & .356 & 4.168 & .336 & Tidak bias \\
\hline \multirow[t]{2}{*}{9} & .362 & 3.929 & .479 & Tidak bias \\
\hline & .362 & 3.929 & .451 & Tidak bias \\
\hline \multirow[t]{3}{*}{10} & .259 & 3.846 & .546 & Perlu \\
\hline & & & & diwaspadai \\
\hline & .259 & 3.846 & .773 & $\begin{array}{c}\text { Perlu } \\
\text { diwaspadai }\end{array}$ \\
\hline \multirow[t]{2}{*}{11} & .306 & 4.276 & .289 & Tidak bias \\
\hline & .306 & 4.276 & .389 & Tidak bias \\
\hline \multirow[t]{2}{*}{12} & .328 & 4.385 & .245 & Tidak bias \\
\hline & .328 & 4.385 & .482 & Tidak bias \\
\hline \multirow[t]{2}{*}{13} & .461 & 3.853 & .447 & Tidak bias \\
\hline & .461 & 3.853 & .504 & Tidak bias \\
\hline \multirow[t]{2}{*}{14} & .358 & 3.648 & .437 & Tidak bias \\
\hline & .358 & 3.648 & .660 & Tidak bias \\
\hline \multirow[t]{2}{*}{15} & .233 & 3.917 & .273 & Perlu \\
\hline & .233 & 3.917 & .383 & $\begin{array}{c}\text { diwaspadai } \\
\text { Perlu } \\
\text { diwaspadai }\end{array}$ \\
\hline \multirow[t]{2}{*}{16} & .354 & 4.338 & .208 & Tidak bias \\
\hline & .354 & 4.338 & .215 & Tidak bias \\
\hline \multirow[t]{2}{*}{17} & .404 & 3.829 & .485 & Tidak bias \\
\hline & .404 & 3.829 & .501 & Tidak bias \\
\hline \multirow[t]{2}{*}{18} & .398 & 4.041 & .300 & Tidak bias \\
\hline & .398 & 4.041 & .271 & Tidak bias \\
\hline \multirow[t]{2}{*}{19} & .297 & 4.165 & .380 & Perlu \\
\hline & .297 & 4.165 & .396 & $\begin{array}{c}\text { diwaspadai } \\
\text { Perlu } \\
\text { diwaspadai }\end{array}$ \\
\hline \multirow[t]{2}{*}{20} & .389 & 4.205 & .300 & Tidak bias \\
\hline & .389 & 4.205 & .243 & Tidak bias \\
\hline
\end{tabular}

Keterangan: Bagian atas untuk kelompok

perempuan, bagian bawah untuk kelompok laki-laki

Apabila model scalar invariance tidak fit, maka yang peneliti lakukan adalah harus 


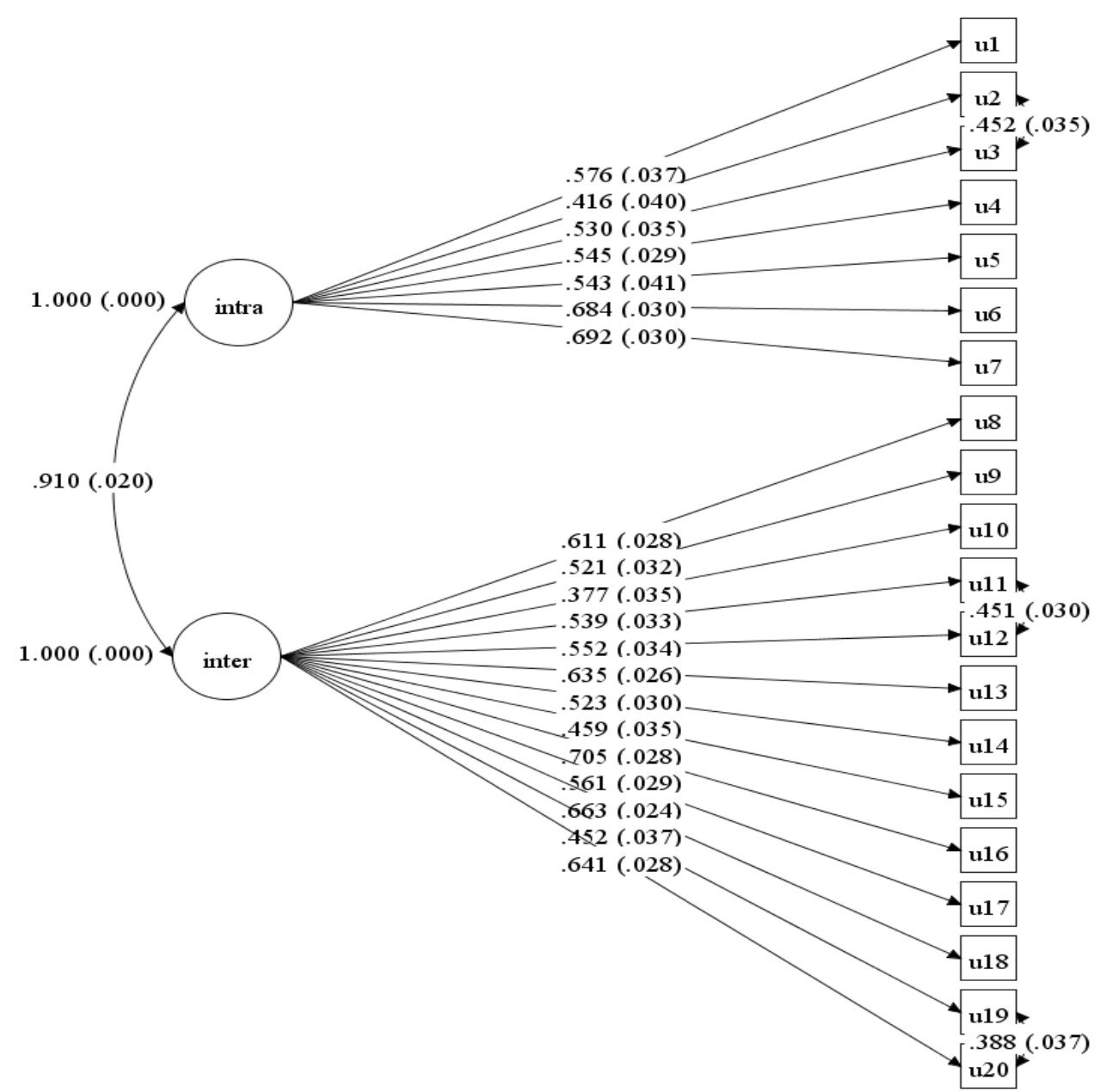

Gambar 2. Model multidimensional pada kelompok gabungan

menurunkan tingkat analisisnya ke metrix invariance, bahkan bisa juga ke configural invariance. Namun, apabila model scalar invariance yang diujikan fit, maka peneliti dapat melakukan analisis lanjutan sampai ke residual invariance.

Pengujian pada scalar invariance $\chi^{2}(377)=$ 1062.251, $p<.05 \&$ RMSEA $<.08$ menunjukkan bahwa seluruh item pada alat ukur ITS memberikan makna yang sama antar kelompok yang diujikan, dalam arti adil untuk kelompok perempuan ( $\chi^{2}$ sebesar 673.309) maupun kelompok laki-laki $\left(\chi^{2}\right.$ sebesar 388.942) hasil analisis dapat dilihat pada tabel 6. Dapat dilihat juga nilai loading factor dan intercept alat ukur ITS memiliki nilai yang sama, hanya nilai residual yang berbeda antar kelompok.

Terdapat lima item pada alat ukur ITS yang perlu diwaspadai dalam penganalisisan yakni: item 1 , item 5 , item 10 , item 15 , dan item 19. Perlu diwaspadai dalam hal ini memiliki arti bahwa alat ukur ITS baru tahap awal dikembangkan oleh peneliti dan dianalisis dengan MGCFA, jadi peneliti berasumsi untuk kelima item yang nilai factor loading-nya di bawah .30 masih dapat digunakan dalam penganalisisan selanjutnya. Pada awal analisis CFA, ITS memiliki nilai loading factor yang baik, pada analisis MGCFA terjadi penurunan nilai loading factor yang tidak terlalu banyak. Alat ukur baru yang dikembangkan akan selalu menimbulkan temuan yang baru juga dalam penganalisisannya.

Tahapan scalar invariace terpenuhi dalam penganalisisan ini, maka dapat dilakukan tahapan pengujian MI pada model selanjutnya, yakni residual invariance. Pada penganalisisan residual invariance, peneliti melakukan konstrain loading factor, intercept dan residual antar kelompok pada model residual invariance. 
Tabel 7

Residual Invariance ITS

\begin{tabular}{|c|c|c|c|c|}
\hline $\begin{array}{l}\text { No } \\
\text { Item }\end{array}$ & $\begin{array}{c}\text { Factor } \\
\text { Loading }\end{array}$ & Intercept & Residual & Hasil \\
\hline \multirow[t]{2}{*}{1} & .266 & 4.475 & .264 & Perlu \\
\hline & .266 & 4.475 & .264 & $\begin{array}{c}\text { diwaspadai } \\
\text { Perlu } \\
\text { diwaspadai }\end{array}$ \\
\hline \multirow[t]{2}{*}{2} & .350 & 3.772 & .762 & Tidak bias \\
\hline & .350 & 3.772 & .762 & Tidak bias \\
\hline \multirow[t]{2}{*}{3} & .394 & 4.093 & .559 & Tidak bias \\
\hline & .394 & 4.093 & .559 & Tidak bias \\
\hline \multirow[t]{2}{*}{4} & .386 & 4.015 & .439 & Tidak bias \\
\hline & .386 & 4.015 & .439 & Tidak bias \\
\hline \multirow[t]{2}{*}{5} & .269 & 4.615 & .302 & Perlu \\
\hline & .269 & 4.615 & .302 & $\begin{array}{l}\text { diwaspadai } \\
\text { Perlu } \\
\text { diwaspadai }\end{array}$ \\
\hline \multirow[t]{2}{*}{6} & .359 & 4.480 & .245 & Tidak bias \\
\hline & .359 & 4.480 & .245 & Tidak bias \\
\hline \multirow[t]{2}{*}{7} & .346 & 4.483 & .221 & Tidak bias \\
\hline & .346 & 4.483 & .221 & Tidak bias \\
\hline \multirow[t]{2}{*}{8} & .357 & 4.167 & .319 & Tidak bias \\
\hline & .357 & 4.167 & .319 & Tidak bias \\
\hline \multirow[t]{2}{*}{9} & .362 & 3.929 & .472 & Tidak bias \\
\hline & .362 & 3.929 & .472 & Tidak bias \\
\hline \multirow[t]{2}{*}{10} & .251 & 3.837 & .609 & Perlu \\
\hline & .251 & 3.837 & .609 & $\begin{array}{c}\text { diwaspadai } \\
\text { Perlu } \\
\text { diwaspadai }\end{array}$ \\
\hline \multirow[t]{2}{*}{11} & .303 & 4.271 & .317 & Tidak bias \\
\hline & .303 & 4.271 & .317 & Tidak bias \\
\hline \multirow[t]{2}{*}{12} & .313 & 4.372 & .312 & Tidak bias \\
\hline & .313 & 4.372 & .312 & Tidak bias \\
\hline \multirow[t]{2}{*}{13} & .463 & 3.855 & .460 & Tidak bias \\
\hline & .463 & 3.855 & .460 & Tidak bias \\
\hline \multirow[t]{2}{*}{14} & .362 & 3.640 & .497 & Tidak bias \\
\hline & .362 & 3.640 & .497 & Tidak bias \\
\hline \multirow[t]{2}{*}{15} & .234 & 3.911 & .302 & Perlu \\
\hline & .234 & 3.911 & .302 & $\begin{array}{c}\text { Perlu } \\
\text { diwaspadai }\end{array}$ \\
\hline \multirow[t]{2}{*}{16} & .353 & 4.339 & .211 & Tidak bias \\
\hline & .353 & 4.339 & .211 & Tidak bias \\
\hline \multirow[t]{2}{*}{17} & .408 & 3.830 & .487 & Tidak bias \\
\hline & .408 & 3.830 & .487 & Tidak bias \\
\hline \multirow[t]{2}{*}{18} & .395 & 4.040 & .293 & Tidak bias \\
\hline & .395 & 4.040 & .293 & Tidak bias \\
\hline \multirow[t]{2}{*}{19} & .298 & 4.166 & .385 & Perlu \\
\hline & .298 & 4.166 & .385 & $\begin{array}{c}\text { diwaspadai } \\
\text { Perlu } \\
\text { diwaspadai }\end{array}$ \\
\hline \multirow[t]{2}{*}{20} & .389 & 4.202 & .284 & Tidak bias \\
\hline & .389 & 4.202 & .284 & Tidak bias \\
\hline
\end{tabular}

Keterangan: Bagian atas untuk kelompok perempuan, bagian bawah untuk kelompok laki-laki

Dari hasil konstrain tiga parameter tersebut, didapatkan nilai model fit $\chi^{2}{ }_{(397)}=$ $1145.633, p<.05 \&$ RMSEA $<.08$ artinya model residual invariance fit dan seluruh item berlaku adil bagi kelompok perempuan $\left(\chi^{2}\right.$ sebesar 707.606) dan kelompok laki-laki $\left(\chi^{2}\right.$ sebesar 438.027). Berlaku adil bisa disebut juga tidak bias untuk penafsirannya. Pada tabel 7 dapat dilihat nilai loading factor, intercept dan residual alat ukur ITS sama antar kelompok.

Hasil analisis residual invariance pun menunjukkan bahwa terdapat lima item yang perlu diwaspadai (nomor item yang perlu diwaspadai sama dengan pengujian scalar invariance, yakni item 1 , item 5 , item 10 , item 15, dan item 19). Namun pada residual invariance item 1, item 5, item 15, dan item 19 mengalami kenaikan nilai loading factor sebesar .001 - .011, sedangkan untuk item 10 terjadi penurunan nilai loading factor sebesar .008. Kenaikan atau penuruan nilai loading factor tidak terlalu besar, dapat dimaknai pula bahwa seluruh item stabil atau konsisten.

\section{Diskusi}

Terdapat lima hal yang akan dibahas dari penelitian ini, yakni: 1) mengenai konsep tawadhu dan humility yang memiliki kesamaan dalam aspek; 2) model pengujian ITS mengikuti aspek tawadhu dari Munawaroh (2018) atau humility dari Davis dkk. (2017); 3) perbandingan alat ukur ITS dengan Skala Tawadhu (Munawaroh, 2018) dari sisi konsep Islam; 4) perbandingan hasil alat ukur ITS dengan Relational Humility Scale (Davis dkk., 2011) dari sudut Psikologi; dan 5) item-item ITS yang perlu diwaspadai. Pertama, ITS pada dasarnya merupakan alat ukur yang memadukan konsep Islami dan Psikologi. Awal mula peneliti memilih topik tawadhu ini disebabkan terdapat konsep yang hampir serupa antara tawadhu dan humility. Pada penelitian yang dilakukan Munawaroh (2018), peneliti mendapatkan penegasan bahwa tawadhu dan humility merupakan konsep yang sama.

Kemudian peneliti melakukan kajian ayatayat Alquran dan Hadis yang berkaitan dengan tawadhu. Dari ayat-ayat dan Hadis yang ditelusuri, ternyata peneliti mendapatkan bahwa tawadhu dan humility memiliki pola 
pembentukan aspek yang berbeda (tawadhu dari pengeksplorasian faktor, sedangkan humility merujuk pada teori), tetapi indikator dari dua variabel tersebut mengukur hal yang sama. Dari hal tersebut dapat dijelaskan bahwa konsep dalam agama Islam pada dasarnya senada dengan ilmu yang lahir di Barat. Hal ini menguatkan peneliti bahwa ilmu dan agama sangat erat kaitannya, bahkan bisa menjadi satu paduan yang menarik untuk dibahas.

Kedua, seluruh aspek tawadhu yakni berlaku lemah lembut, tidak merasa lebih baik dari orang lain, kesetaraan dan mendahulukan kepentingan orang lain tersebut peneliti polakan dengan humility dari Davis dkk. ditemukan bahwa aspek yang diukur sama, seperti yang telah dibahas pada bagian pendahuluan. Oleh sebab itu, peneliti menggunakan pola similarization. Berdasarkan perpaduan tersebut, peneliti mendapatkan hasil bahwa pengembangan Psikologi Islam dapat dieksplorasi lebih mendalam, dalam proses pengukuran.

Sarihat (2018) dalam penelitiannya berpendapat bahwa dengan adanya tawadhu pada diri seseorang akan membuat hubungan intrapersonal dan hubungan interpersonalnya menjadi lebih baik. Argumentasi tersebut peneliti gunakan dalam penelitian ini untuk menentukan model pengujian alat ukur. Munawaroh (2018) menemukan empat aspek, sedangkan penelitian ini menggunakan model berdasarkan pendapat Sarihat (2018). Menurut Sarihat disarankan pengukurannya menggunakan dua komponen yakni hubungan intrapersonal dan interpersonal, yang mana masing-masing komponen sudah diwakili oleh aspek yang diukur.

Ketiga, mengenai perbandingan ITS dan Skala Tawadhu (Munawaroh, 2018) secara teoretis dan analisis. ITS secara teoretis diturunkan menjadi dua dimensi yang terbagi ke dalam tujuh indikator, yakni humble, selfenchancement, respect for others, empathy, lack of superiority, social acceptance, dan openess. Berbeda dengan Skala Tawadhu memiliki empat dimensi dari sebelas indikator, yakni tidak membanggakan diri, menerima ilmu dari siapapun, menghargai orang lain, ringan tangan, bergaul dengan siapapun, mementingkan kepentingan orang lain, tidak mengandalkan orang lain, mengharapkan tempat terbaik dari Allah Swt., tidak membeda-bedakan sesama, tidak merendahkan orang lain, dan bertutur kata yang baik.

ITS memiliki tujuh indikator dan Skala Tawadhu memiliki sebelas indikator, namun apabila diamati dengan seksama, indikator yang yang terdapat pada ITS maupun Skala Tawadhu memiliki kesamaan, misalnya humble dengan 'bertutur kata yang baik', openess dengan 'bergaul dengan siapapun', respect for others dengan 'mementingkan kepentingan orang lain', self-enchancement dengan 'tidak merendahkan orang lain'. Dalam penganalisisan statistik ITS dan Skala Tawadhu berbeda, jadi tidak dapat dibandingkan hasil analisisnya antara ITS dan Skala Tawadhu, hanya dari sisi teoretis yang dapat dibandingkan.

Keempat, perbandingan alat ukur ITS dengan Relational Humility Scale (RHS) yaitu alat ukur rendah hati pada penelitian yang dilakukan Davis dkk. (2011). Secara teoretis RHS juga memiliki dua dimensi intrapersonal dan interpersonal. Namun dalam penganalisisannya RHS menggunakan perpaduan Exploratory Factor Analysis (EFA) dan Confirmatory Factor Analysis (CFA). Dalam analisis EFA dari RHS terbentuk tiga faktor yakni global humility, superiority, dan accurate view self. Selanjutnya hasil CFA tiga faktor yang didapatkan menggunakan program MPlus untuk 300 partisipan pada RHS didapatkan nilai $\chi_{(101)}^{2}=168.21, p<.01 \&$ RMSEA $=.060$, CFI $=.960$ (Davis dkk., 2011). Berbeda dengan ITS, ITS tidak menganalisis menggunakan EFA, karena secara konsep sudah sesuai dengan argumentasi Sarihat (2018), peneliti secara langsung menganalisisnya dari dua faktor yang ada dalam tawadhu. Dari penganalisisan terhadap 613 partisipan pada ITS, didapatkan nilai $\chi_{(166)}^{2}=755.494, p<.05$ $\&$ RMSEA $=.076, \mathrm{CFI}=.908$.

Alat ukur ITS maupun RHS dalam penganalisisannya sama-sama menggunakan software MPlus dan menggunakan konsep yang 
sama, yang berbeda hanya banyaknya item. ITS dengan dua puluh item dan RHS dengan enam belas item. ITS dan RHS sama-sama memiliki nilai indeks model fit yang baik, apabila patokan kriteria model fit yang digunakan oleh peneliti sama yaitu RMSEA < .08 dan CFI > .90 maka indeks model fit terpenuhi, dalam arti sama-sama layak dan valid digunakan dalam penelitian mengenai rendah hati.

Keunggulan ITS dibandingkan alat ukur rendah hati sebelumnya adalah, alat ukur ITS dianalisis dengan menggunakan MGCFA untuk mengetahui bias item dan terpenuhi sampai tahapan terakhir, yakni residual invariance. Berdasarkan penelusuran peneliti, baik RHS dan alat ukur lainnya (Comprehensive Intellectual Humility Scale, Experience Humility Scale, Honesty Humility Scale, Multidimensional Cultural Humility Scale, Rosemade Humility Scale) tidak melakukan pengujian MI, sehingga belum dapat dipastikan bahwa alat ukur lainnya sudah bebas dari bias.

Kelima, hal yang perlu didiskusikan adalah pada alat ukur ITS terdapat item-item yang perlu diwaspadai (item 1 , item 5 , item 10 , item 15, item 19), ketika melakukan CFA berdasarkan kelompok maupun keseluruhan, seluruh loading factor yang dihasilkan > .3. Ketika dilakukan analisis MGCFA antar kelompok secara bersamaan terjadi penurunan nilai loading factor pada lima item yang perlu diwaspadai (ada pula selisih nilai loading factor-nya berbeda cukup besar).

Sebagai contoh untuk item 1 pada kelompok perempuan didapatkan nilai loading factor sebesar .564, untuk kelompok laki-laki sebesar .610, sedangkan saat dianalisis MI baik itu scalar invariance maupun residual invariance nilai yang dihasilkan di bawah < 30 . Begitu juga dengan item 5, 10, 15, 19. Peneliti beranggapan bahwa kelima item ini yang membuat salah satu indeks model fit menjadi kurang baik, dimana nilai Cumulative Fit Index (CFI) pada scalar invariance dan residual invariance $<.90$.

Keterbatasan dalam penelitian ini adalah peneliti belum menemukan tokoh yang secara detail membahas mengenai tawadhu. Dari berbagai sumber yang didapatkan, sedikit sekali yang melakukan penelitian mendalam mengenai tawadhu. Dengan demikian dalam penelitian selanjutnya diharapkan ditemukan metode yang berbeda dalam mengkonstruk alat ukur tawadhu. Disarankan menggunakan desain penelitian maupun metode pendekatan lainnya dalam membangun Psikologi Islam.

\section{Simpulan}

Dari hasil analisis dapat disimpulkan halhal penting, yakni kedua puluh item yang dibuat peneliti dalam pengujian validitas Aiken menunjukkan seluruh item valid mengukur tawadhu atau rendah hati. Selain valid, dalam pengujian measurement invariance pada scalar invariance dan residual invariance, seluruh item yang dikonstruk tidak bias (diujikan pada kelompok gender). Artinya dapat digunakan oleh siapapun. Perpaduan teori Psikologi, ayatayat Alquran dan Hadis memperlihatkan bahwa ilmu dan agama dapat berpadu dalam pemanfaatannya, khususnya penelitian. Penelitian ini juga menunjukkan terdapat lima item (item 1, item 5, item 10, item 15, item 19) yang perlu diwaspadai, sehingga untuk penggunaan pada penelitian selanjutnya, kelima item tersebut dapat digunakan, namun dapat pula dihilangkan guna mencapai model fit yang sangat baik.

\section{Referensi}

Ad-Dimasyqi, A. A. F. I. I. K (2000). Tafsir ibnu katsir (Bakar, Terj.). Sinar Baru Algensindo.

Aiken, L. R. (1985). Three coefficient for analyzing the reliability and validity of rating. Education and Psychological Measurement, 45, 131-142. https://doi.org/10.1177/001316448545101 2

Akhyar, Y., \& Wilaela. (2018). The personality of ibadurrahman in Quran (Character education construction in building civilization). Jurnal Ushuludin, 26(2), 154165.

http://dx.doi.org/10.24014/jush.v26i2.4899 
Bilicha, P. N., Bachry, P. N., Rakhmandari, R. A., \& Rusdi, A. (2019). Komunikasi interpersonal mahasiswa ditinjau dari tawadhu dan penyesuaian diri. Jurnal Psikologi Islami, 5(2), 109-118. https://doi.org/10.19109/psikis.v5i2.3890

Cohen, R. J., Swerdlik, M. E., \& Sturman, E. D. (2013). Psychological testing and assessment: An introduction to tests and measurement (Ed. 8). McGraw-Hill Companies.

Darma, Y. (2020). Konsep pendidikan akhlak menurut Ibn Khaldun (Skripsi tidak diterbitkan). Universitas Islam Negeri ArRaniry, Fakultas Tarbiyah dan Keguruan.

Chompalov, K. A., Atanassova, P. A., Massaldjieva, R. I., Bahchevanov, K. M., Milev, B. A., Naydenov, V. A., ... Semerdzhieva, M. A. (2018). Vascular risk factors in bulgarian volunteers in middle adulthood. Folia Medica, 60(4), 565-570. https://doi.org/10.2478/folmed-2018-0039

Davis, D. E., \& Hook, J. N. (2014). Humility, religion, and spirituality: An endpiece. Journal of Psychology and Theology, 42(1),

111-117. https://doi.org/10.1177/009164711404200 112

Davis, D. E., Hook, J. N., Worthington, E. L., Van Tongeren, D. R., Gartner, A. L., Jennings, D. J., \& Emmons, R. A. (2011). Relational humility: Conceptualizing and measuring humility as a personality judgment. Journal of Personality Assessment, 93(3), 225-234. https://doi.org/10.1080/00223891.2011.55 8871

Davis, D. E., McElroy, S., Choe, E., Westbrook, C. J., DeBlaere, C., Van Tongeren, D. R., ... Placeres, V. (2017). Development of the experiences of humility scale. Journal of Psychology and Theology, 45(1), 3-16. https://doi.org/10.1177/009164711704500 101

Davis, D. E., Worthington, E. L., \& Hook, J. N. (2010). Humility: Review of measurement strategies and conceptualization as personality judgment. Journal of Positive Psychology, 5(4), 243-252. https://doi.org/10.1080/174397610037916 72

DeCoster, J. (2005). Scale construction notes. http://www.stat-help.com/notes.html

D'Errico, F. (2020). Humility-based persuasion: Individual differences in elicited emotions and politician evaluation. International Journal of Communication, 14(2020), 3007-3026.

Gade, S. (2019). Membumikan pendidikan akhlak mulia anak usia dini. PT. Naskah Aceh Nusantara.

Gonzalez, E., Sperandio, K. R., Mullen, P. R., \& Tuazon, V. E. (2020). Development and initial testing of the multidimensional cultural humility scale. Measurement and Evaluation in Counseling and Development, $\quad 0(0), \quad 1-16$. https://doi.org/10.1080/07481756.2020.17 45648

Hidayanti, S. N. (2016). Pengembangan skala tawadhu (Skripsi tidak diterbitkan). Universitas Islam Indonesia, Fakultas Psikologi.

Ho, S. Y., Rohan, K. J., Parent, J., Tager, F. A., \& McKinley, P. S. (2015). A longitudinal study of depression, fatigue, and sleep disturbances as a symptom cluster in women with breast cancer. Journal of Pain and Symptom Management, 49(4), 707715. https://doi.org/10.1016/j.jpainsymman.201 4.09.009

Krumrei-Mancuso, E. J., \& Rouse, S. V. (2016). The development and validation of the comprehensive intellectual humility scale. Journal of Personality Assessment, 98(2), 209-221. https://doi.org/10.1080/00223891.2015.10 68174

Kruse, E., Chancellor, J., \& Lyubomirsky, S. (2017). State humility: Measurement, conceptual validation, and intrapersonal processes. Self and Identity, 16(4), 399438. https://doi.org/10.1080/15298868.2016.12 
67662

Libriastuti, F., \& Sudewo, P. A. (2016, Oktober 17-18). Dinamika psikologis tawadhu mahasiswa terhadap gurunya. (Presentasi paper). Seminar Nasional dan Gerak Produk, UMM, Indonesia.

Meredith, W. (1993). Measurement invariance, factor analysis, and factorial invariance. PSYCHOMETRIKA, 58(4), 525-543. https://doi.org/10.1007/BF02294825

Mujib, A. (2005). Pengembangan psikologi Islam melalui pendekatan studi Islam. Jurnal Psikologi Islami, 1(1), 17-32.

Munawaroh, U. (2018). Hubungan antara tawadhu dan kesejahteraan psikologis pada mahasiswa santri (Skripsi tidak diterbitkan). Universitas Islam Indonesia, Fakultas Psikologi.

Pardilah, P. (2020). Rendah hati dalam perspektif Imam Al-Qurthubi (Kajian tafsir al-jami li ahkami al-quaran) (Skripsi tidak diterbitkan). Universitas Islam Sultan Maulana Hassanudin Banten, Fakultas Ushuludin.

Qin, X., Chen, C., Yam, K. C., Huang, M., \& $\mathrm{Ju}, \mathrm{D}$. (2020). The double-edged sword of leader humility: Investigating when and why leader humility promotes versus inhibits subordinate deviance. Journal of Applied Psychology, 105(7), 693-712. https://doi.org/10.1037/apl0000456

Rohman, T. (2020). Mata pelajaran akidah akhlak sebagai sarana pembiasaan sikap tawadhu. Al-Tarbawi Al-Haditsah: Jurnal Pendidikan Islam, 5(1), 122-146. https://doi.org/10.24235/tarbawi.v5i1.6353

Rozak, P. (2017). Indikator tawadhu dalam keseharian. Jurnal Madaniyah, 7(1), 174187.

Salsabila, D. F., Rofifah, R., Natanael, Y., \& Ramdani, Z. (2019). Uji validitas konstruk indonesian-psychological measurement of islamic religiousness (I-PMIR). JPIB : Jurnal Psikologi Islam dan Budaya, 2(2), $1-10$.

https://doi.org/10.15575/jpib.v2i2.5494

Sarihat. (2019). Sifat tawadhu hafidz alquran. Jurnal Studia Insania, 6(2), 158-172. http://dx.doi.org/10.18592/jsi.v6i2.2212

Tanidir, Y., Mangir, N., Sahan, A., \& Sulukaya, M. (2017). Turkish version of the ureteral stent symptoms questionnaire: Linguistic and psychometric validation. World Journal of Urology, 35(7), 1149-1154. https://doi.org/10.1007/s00345-016-1958-4 Tarsono, T., Mansyur, A. S., \& Ruswandi, U. (2020). Pengembangan kurikulum pendidikan moral agama pada pendidikan taman kanak-kanak. Psympathic: Jurnal Ilmiah Psikologi, 7(1), 141-154. https://doi.org/10.15575/psy.v7i1.7604

Tiaranita, Y., Saraswati, S. D. \& Nashori, F. (2017). Religiusitas, kecerdasan emosi, dan tawadhu pada mahasiswa pascasarjana. Psikologia (Jurnal Psikologi), 2(1), 2737. https://doi.org/10.21070/psikologia.v2i 1.568

Ummah, U. R. (2017). Nilai-nilai pendidikan akhlak dalam surah Al-furqon ayat 63-67 (Skripsi tidak diterbitkan). Institut Agama Islam Negeri Salatiga, Fakultas Tarbiyah dan Ilmu Keguruan.

Vera, D., \& Rodriguez-Lopez, A. (2004). Strategic virtues: Humility as a source of competitive advantage. Organizational Dynamics, 33(4), 393-408. https://doi.org/10.1016/j.orgdyn.2004.09.0 06

Vijayakumar, N., Allen, N. B., Youssef, G., Dennison, M., Yücel, M., Simmons, J. G., \& Whittle, S. (2016). Brain development during adolescence: A mixed-longitudinal investigation of cortical thickness, surface area, and volume. Human Brain Mapping, $37(6)$, 2027-2038. https://doi.org/10.1002/hbm.23154 